\title{
SCHOOL LEARNING ACTION CELL AS A REMEDY TO OUT-OF-FIELD TEACHING: A CASE IN ONE RURAL SCHOOL IN SOUTHERN PHILIPPINES
}

\author{
Jayson Troy Ferro Bajar1*, Mary Ann Ferro Bajar2, Elizabeth P Alarcon³ \\ 'National Dong Hwa University, Hualien, Taiwan \\ 2Palkan National High School, South Cotabato, Philippines \\ 3Polomolok National High School, South Cotabato, Philippines \\ *jaysontroy46@gmail.com
}

\begin{abstract}
Article Info
Article history

Received February 11, 2021

Revised April 10, 2021

Accepted April 27, 2021

Keywords: Out-of-field teaching; Philippine education; Professional learning community; Rural education; School learning action cell

ABSTRACT

Out-of-field teaching continues to be a persisting problem in the Philippine educational system - similarly evident in the rural school where this study was conducted. As a ontervention, the researchers organized a professional learning community in the form of a school learning action cell (SLAC) to provide assistance to the teachers. They were then interviewed to determine the perceived effects of the intervention. Results of the study revealed that, SLAC sessions contribute to the general well-being of the teachers in their view of the profession as it 'reduced their tasks' and 'promoted workplace collaboration'. On the other hand, it also impacted their pedagogy where it was found to have contributed in their 'instructional mastery' and 'teacher efficacy'. The researchers however caution that, though the intervention was found to be successful, it should be taken in its suggestive nature when out-of-field teaching is unavoidable. When feasible, the idyllic educational landscape should assign teachers according to their respective specialized fields.
\end{abstract}

\section{INTRODUCTION}

The teaching profession has long before characterized by isolationism which consequently limit opportunities for teacher collaboration, sharing of craft, and working together - largely because of the organization of schools as a workplace (Benson, 2011; Lieberman, 2000; Little, 2002). The lack of opportunity for teachers to work together collegially and collaboratively has been identified as a limiting factor in allowing teachers to improve their practices, enhance student learning, and promote sustainable change in the culture of schools (de Jong et al., 2019; Feger \& Arruda, 2008).

Meanwhile, such belief had eventually been replaced as the teaching profession encountered drastic and transformative changes. One of these notable changes is the widespread global recognition of the value of professional learning communities and other forms of organized teacher collaborations as effective ways of improving instructional practices and learning outcomes (Vescio et al., 2008; Watson, 2014). A considerable amount of literature suggests that the building of professional learning communities for greater teacher collaboration is becoming a more attractive and effective strategy in elevating school performance and transforming school culture (Williams et al., 2012). International 
scholarship further supports that professional learning communities hold promise for greater capacity building and sustainable development which cascades into improved student learning (Stoll et al., 2006).

\subsection{Teacher Collaboration in the Teaching Profession}

According to Carroll et al., (2010), 'the era of isolated teachers, working alone to meet the myriad needs of all their students, is neither educationally effective nor economically viable in the 21 st century' $(2010$, p. 7). Therefore, the current educational landscape compels teachers to work together and address instructional needs in collective manner.

Collaboration is a must in order to overcome contemporary school challenges. It is defined as the process of working together through idea and resources sharing to accomplish a common goal (Lai, 2011). Explaining further, it should be systematic process where people musk work interdependently specially in analyzing and reflecting on the impact OF professional practice thus leading to improved individual and collective results (DuFour et al., 2006).

As applied in the teaching profession, effective teacher collaboration is the engagement in regular routines where teachers communicate about classroom experiences with an aim to strengthen pedagogical expertise and encourage colleagues to try new things (Davis, 2003). As such, to enable an effective collaboration, teachers must follow a certain set of routines where they can work together on common instructional issues and thereby work hand-in-hand in solving problems.

Research has shown that collaboration between teachers increases student achievement (Cook \& Friend, 1991). Moreover, several studies astoundingly reveal that teacher collaborations curb feelings of isolation, deter burnout, and boost teacher efficacy (Degan, 2018; Reeves et al., 2017; Skaalvik \& Skaalvik, 2010). Teachers also reported that building partnership of support improved their own effectiveness as teachers, and enhanced their professional performance (Slick, 2002).

Furthermore, Pont et al., (2008) suggested that workplace collaboration encourages collective action in addressing student needs and improve the pedagogical practice of teachers. This was supported in a large-scale survey by Ronfeldt et al., (2015) where they found out that teachers improve at higher rates if they work at schools characterized by higher-quality collaboration than they would if they worked in a school with lower-quality collaboration.

However, the success of teacher collaboration also depends in the access to the administrative support needed to hone their instructional skills (DeMatthews, 2014; Pont et al., 2008). As such, school leaders are imbibed with essential responsibility in fostering a culture of collaboration. Administrators are compelled to provide collaborative professional development programs that continues throughout the school year and maintain such 
practices to be gradually enculturated at their respective school sites (Dutta \& Sahney, 2016).

One way to ensure that teachers actively participate in these kinds of collaborative professional development programs is for the administration to ask a well-respected colleague considered an expert in the subject to lead the charge. Sutton \& Shouse (2016) argue that schools should utilize staffs who are experts in different areas, in such collaborative ways, to better run professional development and trainings. In this sense, teachers are more likely to apply what they learn from their colleagues, rather than a paid outsider, because it feels more meaningful (Sutton \& Shouse, 2016).

\subsection{Learning Action Cells}

No teacher is an expert in all the elements of the curriculum; hence, insights and expertise of other teachers are needed in order to enrich one's knowledge, skill, and competence. Goddard et al., (2015) discovered that teachers who team up and collaborate reported improved attitudes towards teaching, teacher efficacy, and understanding of student learning. Recognizing such need, the Department of Education (DepEd) issued order (D.O.) 35, s. 2016, which sought the institutionalization of Learning Action Cells (LACS) as an approach to develop and support teachers by nurturing their knowledge, attitudes, and competencies in terms of curriculum, instruction, and assessment in their work stations.

The abovementioned DepEd order prescribes LAC as a school-based continuing professional development strategy for the improvement of teaching and learning. The new policy argues that the locus of teacher learning is at the school, and teachers must actively participate in collegial discussions facilitated by the school head or a designated LAC leader in order to solve shared challenges and improve the quality of teaching in the school (D.O. 35, s. 2016).

The LAC model is founded on the numerous researches about the concept of professional learning community which is labelled by experts as the "best hope for reculturing a school' (Humada-Ludeke, 2013, p. 19). However, for this model to be effective, specific set of conditions must be met. Those conditions, according to Dufour \& Marzano, (2011), include: (1) that schools must demonstrate a high level of learning for all students; (2) that teachers must be organized into teams and given time to collaborate; (3) that teams must provide a guaranteed curriculum for every course and grade level; (4) that teachers must develop common assessments; and (5) that evidence-based student learning be used to allow for continuous improvement.

Rey (2000) argues that the success of LAC sessions is strongly attributed to keeping the communication channels open by giving every member the opportunity to share ideas and accept feedbacks. Through open communication, LAC participants are given a space to 
share understandings on the content and pedagogy of teaching. With this space, they are able to help one another in facing challenges brought about by many different school reforms.

Finally, time is another significant factor to be considered for the success of LAC sessions. It is suggested that it must be built into teachers' schedules so that team teachers are able to plan and prepare lessons and reflect on those lessons together (Madigan \& Scroth-Cavataio, 2011). To fully realize this, such built-in-time must earn the support of school administrators and be officially embedded. It is yet another way that administrative support is crucial in developing and maintaining a collaborative culture.

\subsection{Needs Assessment and Intervention Strategy}

In the Philippine educational setting, one of the most pervasive instructional issues is the phenomenon of out-of-field teaching or teachers being assigned to teach subjects outside their educational background or expertise. This long existing issue also finds its way even in the current K-12 program. Though it created a number of teaching positions and stable jobs for the worsening unemployment, it also broadened the already concerning gaps in the educational sector such as qualifications mismatch and consequently out-of-field teaching (Pacana et al., 2019). Teacher shortage continued to be a persisting problem especially for some fields that require specialized knowledge and skill resulting to the notion of settling to what is available (David \& Ducanes, 2018).

In the local context where this study was conducted, out-of-field teachers manifested difficulty in making learning plans, delivering the lessons, and constructing formative and summative assessments. Others clamor that it was a huge burden on their part to teach subjects which they were not trained to teach, especially that the target learners are in the advanced level of basic education.

The increase in population for up to more than $10 \%$ further aggravated such problem. As a consequence, teachers were given six subject teaching loads which require two or three preparations of daily lesson plans (DLP). Aside from these, teachers were also given auxiliary assignments such as advisory and subject- or club coordinator duties.

With these in mind, the researchers conceptualized an intervention strategy aimed at developing measures to assist the out-of-field teachers by organizing a professional learning community in the form of a school learning action cell (SLAC). The intervention sought to encourage "teachers (†o) work interdependently and collaboratively and focus on a shared mission of collective capacity building, identify(ing) learning gaps and develop(ing) effective institutional practices to fulfill the needs of all students" (Sai \& Siraj, 2015, p. 67). The SLAC sessions were also considered as avenues for teachers to discuss and critically reflect on the problems and struggles that they are experiencing in their teaching practice, and collectively devise solutions and strategies to better address those problems and struggles. 
SLAC sessions were organized in several instructional teams for capacity building. Each instructional team is composed of a specialized teacher, or a teacher with substantial knowledge and background on a certain field, who acts as a team leader, and the out-offield teachers as members. The team leader facilitated the mentoring and coaching of colleagues, as well as supervising of the drafting of unified daily lesson plan, assessment and evaluation tools, and leading an open dialogue on how to better introduce difficult topics in their respective classrooms. The SLAC sessions were conducted once every month though teachers were informed that they can consult anytime with the specialized teacher or with each other if they encounter difficulty or confusion in the topics that they will present in class.

In implementing this intervention strategy, the researchers recognized that the solution in out-of-field teaching is not an overnight educational reform by increasing the supply of teachers. Rather, with targeted funding for retraining, implementing localized professional development programs, and mentoring of less specialized teachers, it would be possible to provide opportunities for committed teachers to extend their teaching expertise and maintain high-quality teaching. In addition, it expected that teacher will gain diversified knowledge, improved capacity, and increased their confidence in extended content areas and be introduced to teaching approaches in other disciplines.

\subsection{Research Question}

In assessing the intervention conducted, this study sought to answer the question: What are the perceived effects of utilizing school learning action cells (SLAC) as a remedy to out-of-field teaching?

\section{METHODS}

This is study is a qualitative inquiry in the perceived effect of the SLAC as a remedy to out-of-field teaching. In-depth interviews were conducted to determine the views and experiences of the teachers in a large-sized public secondary high school located in a rural community in southern Philippines. As such, the researchers assume novelty in terms of conducting this study among rural educators. It is though essential that the proponents do not necessarily argue that the locale setting is a prime factor that affected the study outcomes, as it is yet to be investigated. On the other hand, it is the aim of this paper to present views from the perspective of rural education wherein researches are rather scanty and put on peripheries even in the scholarly world.

A total of seven teacher-respondents were included as participants of the study which is already enough upon meeting the suggestions of Cresswell (1998) of having at least five to 25 respondents for a significant saturation of qualitative data. They were purposefully chosen following criteria that: (1) they handle six (6) teaching loads for the current school year with at least two preparations; and (2) they are teaching subjects which are not their 
field of specialization as evaluated based on their academic background and training. Most importantly, the researchers only included teachers who voluntarily participated as suggested by Feger and Arruda (2008).

In analyzing the interviewed data, the researchers followed the six-step thematic analysis framework developed by Braun and Clarke (2006). Furthermore, to systematically identify the coding categories, the three-step systematic coding steps (open, axial, and selective) by Corbin and Strauss (2008) were utilized.

\section{RESULTS AND DISCUSSION \\ CATEGORY MAPPING}

In the open coding stage, the researchers identified codes from the interview transcript. Color coding technique was employed to maximize the extraction of significant codes from the interview transcript. Codes which are related to each other were grouped in the same color. All possible themes were identified but they were later on filtered together from identifying the most dominant emerging codes which are presented in Table 1.

Table 1. Themes in the open coding stage

\begin{tabular}{lll}
\hline Research question & Codes \\
\hline How do teachers perceived the & - Less stressful & - Workplace collaboration \\
effect of utilizing school learning & - Reduced tasks & - Efficacy \\
action cells (SLAC) as a remedy to & - Partnership & - Content mastery \\
out-of-field teaching? & - Camaraderie & - Confidence \\
\hline
\end{tabular}

In the axial coding stage, the researchers re-examined the codes and grouped the similar ones thus identifying broader patterns. In doing this, the researchers were able to identify the initial categories which led to the identification of more global categories. The categories after the axial coding stage are shown in Figure 1.

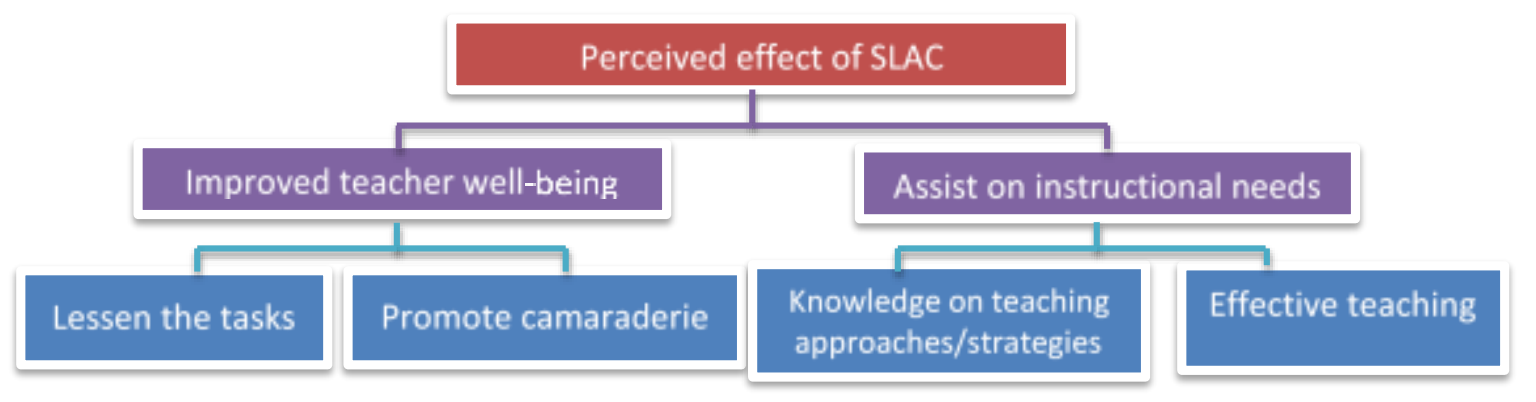

Figure 1. Preliminary categories in axial coding stage

Finally, the last step is the selective coding stage where categories were further related thereby serving as a backbone for an in-depth storyline and a more theory-driven analysis. As such, it is essential to note that such categories serve as the foundation of a strong analysis 
where final core category, major categories, and subcategories are logically placed. The final category mapping after the selective coding stage is presented in Figure 2.

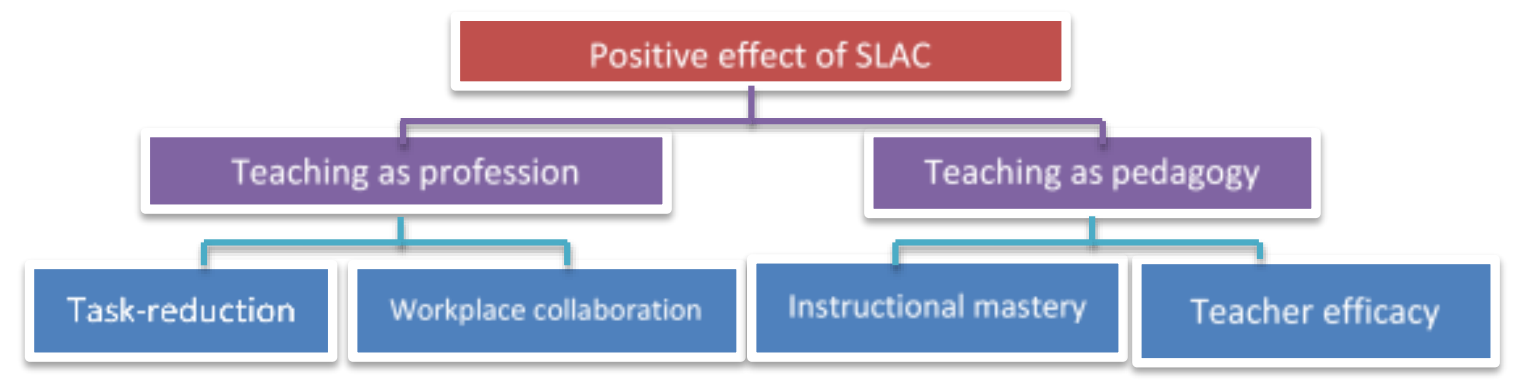

Figure 2. Final category mapping in selective coding stage

\section{DISCUSSIONS}

\section{Perceived effect of the SLAC in 'Teaching as a Profession'}

The teachers positively viewed the conduct of SLAC sessions as a remedy for out-offield teaching. Their responses can be further classified with in relation to its perceived effects as regards to teaching considered as a profession and as regards to teaching as a pedagogy. In the former, the respondents indicated that SLAC sessions (1) reduced their tasks and that (2) it promoted collaboration in the workplace. With these, it can be said therefore that implementing SLAC sessions not only lessened the heavy burden of instructional preparations but also provided opportunities for teachers to work with their colleagues thus defying the isolationist nature of the teaching profession (Benson, 2011; Lieberman, 2000; Little, 2002).

Task-reduction. When the intervention strategy was introduced, teachers were at first unconvinced as they might perhaps be burdened of another auxiliary duties which already consume much of their time. However, when it was made clear to them that the purpose of the intervention was to help them, they gradually changed their attitude as they participate actively in the SLAC sessions. One teacher even indicated that the intervention 'eliminated the feeling of stress' especially in the preparation of daily lesson plans which was deemed time-consuming at an extent that it takes up much of their instructional preparations. To this end, teachers emphasized that having well-prepared instructional materials makes them 'more confident and worry-free' despite teaching in their out-of-field discipline. It can be said that reducing the heavy tasks of the teachers contribute to their greater well-being which may translate to a more effective delivery of classroom instruction (Degan, 2018; Reeves et al., 2017; Skaalvik \& Skaalvik, 2010).

This finding highlights the opportunity whereby teacher responsibilities may be lessened without compromising the quality of instruction. In fact, this strategy offers a viable solution to the 'excessive' yet necessary workload that Filipino teachers are now facing (Tomacruz, 2018) 
Workplace collaboration. Another perceived effect of the intervention was workplace collaboration. The teachers indicated that being able to work with their colleagues allows them to develop more meaningful relationships at work. According to one teacher, the SLAC sessions provided platforms wherein she can discuss 'common challenges and also bond with fellow teachers.' Another teacher stated that it is 'good to develop friendships from other cliques' and thereby expand their network. As the intervention goes by, it created a harmonious work environment where they did not anymore feel distanced and detached from each other. After several sessions, they considered consulting each other as a typical part of their usual days, and not anymore as in a mentor-mentee relationship. They felt 'ease at communicating with each other's difficulties' and 'thinking of ways together' to solve such problems.

Isolationist educational culture must not be a norm in the 21 st century education (Carroll et al., 2010). As such, workplace collaboration must be promoted to create a culture of open communication among teachers where they can discus about their experiences in the classroom and further develop their teaching practice (Davis, 2003). This study reveals that SLAC sessions provide a platform wherein collaborative work can eventually become a part and parcel of school culture and re-culturing (de Jong et al., 2019; Humada-Ludeke, 2013).

\section{Perceived Effect of the SLAC in 'Teaching as a Pedagogy'}

The second major category extracted from the thematic analysis of the transcribed interview is the perceived effect of the SLAC in teaching as a pedagogy. In this category, two subcategories were identified: (1) teacher efficacy and (2) instructional mastery. The respondents stressed that the intervention, in a form of being a professional learning community, allowed them to re-examine their teaching practices and further hone them by adopting to the appropriate teaching approaches as applied in other specialized disciplines (Vescio et al., 2008; Watson, 2014).

Instructional mastery. One of the top and persisting concerns in out-of-field teaching is the mastery of both the content and the method in delivering lessons especially on specialized topics. One teacher re-echoed this concern saying that they may gradually 'learn the method but would certainly find difficulty in the mastery of content.' As a response, teachers were reminded that no topic would be very difficult to grasp with appropriate teaching strategies. As such, they were made realized that no teaching strategy fits in all context and that variation is needed thus the conduct of the SLAC sessions. In some occasions, the SLAC sessions included micro-teaching demonstration wherein teachers could have a direct experience in the employment of suggested use of teaching approaches and strategies. Sharing of supplementary materials and references were also observed. In the end, teachers confessed that the SLAC sessions 'help them to become 
knowledgeable not only in teaching but also in the content areas' of the specialized disciplines which is essential as they deliver the subjects.

Being a teacher entails a commitment towards a lifelong learning though it is also essential to take in mind that no person will have a monopoly of knowledge. With this, teachers can engage in an intellectual exchange of expertise among their colleagues to seam together the learning gaps through capacity building and thereby developing effective institutional practices (Sai \& Siraj, 2015; Stoll et al., 2006).

Teacher efficacy. One of the persisting dilemmas encountered by most educators is the ease of delivering the lessons effectively. Teachers think of many innovative ways to ensure that learning really takes place in the classroom. This problem is however aggravated much in the case of out-of-field teachers. One respondent said that 'instructional competence in (one's) specialized field is even difficult to fully master' and even more in the case when it is not one's academic training. As such, when the intervention was implemented, teachers participated in an open dialogue mediated by the LAC leader and were able to talk about their concerns particularly on how certain topics are to be appropriately delivered. The healthy exchange of ideas led to a synergy of different teaching styles where teachers 'not necessarily adopt to a new teaching method' but 'broaden one's (pedagogical) experience'. In addition, by using the unified instructional materials, teachers indicated that they became 'more prepared and confident' to take the class even if it is not their specialized fields. Indeed, with appropriate preparations, teachers can be flexible enough to deliver the lessons with greater ease (Jensen, 2002).

For teachers to fully realize their maximum potentials, they must be involved in professional learning communities that will allow them to reflect in their professional practice with others and envision collective results (DuFour et al., 2006). The SLAC sessions can provide this leverage at the advantage of teachers and subsequently as it will cascade into increase student achievement (Cook \& Friend, 1991).

\section{CONCLUSION}

This study was conducted to determine the perceived effects of a school learning action cell (SLAC) as a remedy in out-of-field teaching. It was found out that teachers elicited responses which can be categorized as regards with 'teaching as a profession' and 'teaching as a pedagogy'. It was further revealed that, for the former, SLAC sessions contribute in 'task-reduction' and 'workplace collaboration'. On the other hand, it was also found out that, on the latter, SLAC sessions contribute in 'instructional mastery' and 'teacher efficacy'.

While this study suggests that that the SLAC sessions proved to be a helpful mechanism as a remedy, the researchers also want to emphasize that these findings are to be taken in its suggestive nature when out-of-field teaching is unavoidable. At an idyllic 
educational landscape, it is without contradiction that teachers be assigned in their respective specialized backgrounds. In the latter end, teachers undergone different sets of trainings which they should also utilize in their professional practice.

\section{ACKNOWLEDGEMENTS}

The researchers would like to thank the co-teachers for actively participating in this study. In addition, the researchers also express their warmest gratitude to those who help in the fruition and success of this study.

\section{REFERENCES}

Benson, P. (2011). What's new in autonomy? The Language Teacher, 35(4), 15. https://doi.org/10.37546/JALTTLT35.4-4.

Braun, V., \& Clarke, V. (2006). Using thematic analysis in psychology. Qualitative Research in Psychology, 3(2), 77-101. https://doi.org/10.1191/1478088706qp063oa.

Carroll, T. G., Fulton, K., \& Doerr, H. (2010). Team up for the 21 st century teaching and learning: What research and practice reveal about professional learning. https://files.eric.ed.gov/fulltext/ED512177.pdf.

Cook, L., \& Friend, M. (1991). Principles for the practice of collaboration in schools. Preventing School Failure: Alternative Education for Children and Youth, 35(4), 6-9. https://doi.org/10.1080/1045988X.1991.9944251.

Corbin, J., \& Strauss, A. (2008). Basics of qualitative research: Techniques and procedures for developing Grounded Theory (3rd ed.). SAGE Publications, Inc. https://doi.org/10.4135/9781452230153.

Creswell, J. W. (1998). Qualitative inquiry and research design: Choosing among five traditions. In Qualitative Health Research. SAGE Publications, Inc.

David, C. C., \& Ducanes, G. (2018). Teacher education in the Philippines: Are we meeting the demand for quantity and quality? (No. 18-002: Center for Integrative and Development Studies - University of the Philppines). https://cids.up.edu.ph.

Davis, K. S. (2003). "Change is hard": What science teachers are telling us about reform and teacher learning of innovative practices. Science Education, 87(1), 3-30. https://doi.org/10.1002/sce.10037.

de Jong, L., Meirink, J., \& Admiraal, W. (2019). School-based teacher collaboration: Different learning opportunities across various contexts. Teaching and Teacher Education, 86, 102925. https://doi.org/10.1016/j.tate.2019.102925.

Degan, J. (2018). Stronger together: A case for team teaching in the elementary school setting [Master's Thesis: Dominican University of California]. https://doi.org/10.33015/dominican.edu/2018.edu.01.

DeMatthews, D. (2014). Principal and teacher collaboration: An exploration of distributed 
leadership in professional learning communities. International Journal of Educational Leadership and Management, 2(2), 176-206. https://doi.org/10.17583/ijelm.2014.1068.

DuFour, R., DuFour, R., Eaker, R., Many, T., \& Mattos, M. (2006). Learning by doing: A handbook for professional learning communities at work (3rd ed.). Solution Tree.

Dufour, R., \& Marzano, R. J. (2011). Leaders of learning : How district, school, and classroom leaders improve student achievement. In Leading Professional Learning Communities. Solution Tree.

Dutta, V., \& Sahney, S. (2016). School leadership and its impact on student achievement. International Journal of Educational Management, 30(6), 941-958. https://doi.org/10.1108/IJEM-12-2014-0170.

Feger, S., \& Arruda, E. (2008). Professional learning communities: Key themes from the literature. The Education Alliance - Brown University. https://www.brown.edu.

Goddard, R., Goddard, Y., Sook Kim, E., \& Miller, R. (2015). A theoretical and empirical analysis of the roles of instructional leadership, teacher collaboration, and collective efficacy: Beliefs in support of student learning. American Journal of Education, 121 (4), 501-530. https://doi.org/10.1086/681925.

Humada-Ludeke, A. (2013). The creation of a professional learning community for school leaders. Sense Publishers. https://doi.org/10.1007/978-94-6209-320-1.

Jensen, L. (2002). Planning lessons. In M. Celce-Murcia (Ed.), Teaching English as a second or foreign language (3rd ed., pp. 403-413). Heinle \& Heinle.

Lai, E. (2011). Collaboration: A literature review. www.pearsonassessments.com

Lieberman, A. (2000). Networks as learning communities shaping the future of teacher development. Journal of Teacher Education, 51(3), 221-227. https://doi.org/10.1177/0022487100051003010.

Little, J. W. (2002). Professional community and the problem of high school reform. International Journal of Educational Research, 37(8), 693-714. https://doi.org/10.1016/S0883-0355(03)00066-1.

Madigan, J. C., \& Scroth-Cavataio, G. (2011). IDEIA 2004: Building collaborative partnerships and effective communication between administrators, special and general educators, and multidisciplinary professionals. Principal Leadership, 12(3), 26-30. https://eric.ed.gov/?id=EJ965260.

Pacana, N. M. S., Ramos, C. D., Catarata, M. N., \& Inocian, R. B. (2019). Out-of-field social studies teaching through sustainable culture-based pedagogy: A Filipino perspective. International Journal of Education and Practice, 7(3), 230-241. https://doi.org/10.18488/journal.61.2019.73.230.241.

Pont, B., Nusche, D., \& Moorman, H. (2008). Improving school leadership: Policy and practice. OECD Publishing. www.oecd.com

Reeves, P. M., Pun, W. H., \& Chung, K. S. (2017). Influence of teacher collaboration on job 
satisfaction and student achievement. Teaching and Teacher Education, 67, 227-236. https://doi.org/10.1016/j.tate.2017.06.016.

Rey, E. (2000). Factors affecting the efficiency of the LAC for grades 1 and 2 teachers in the Division of Masbate. Bicol University, Legazpi, Philippines.

Ronfeldt, M., Farmer, S. O., McQueen, K., \& Grissom, J. A. (2015). Teacher collaboration in instructional teams and student achievement. American Educational Research Journal, 52 (3), 475-514. https://doi.org/10.3102/0002831215585562.

Sai, X., \& Siraj, S. (2015). Professional learning community in education: Literature review. The Online Journal of Quality in Higher Education, 2(2), 65-78.

Skaalvik, E. M., \& Skaalvik, S. (2010). Teacher self-efficacy and teacher burnout: A study of relations. Teaching and Teacher Education, 26(4), 1059-1069. https://doi.org/10.1016/j.tate.2009.11.001.

Slick, S. (2002). Teachers are enthusiastic participants in a learning community. The Clearing House: A Journal of Educational Strategies, Issues and Ideas, 75(4), 198-201. https://doi.org/10.1080/00098650209604931.

Stoll, L., Bolam, R., McMahon, A., Wallace, M., \& Thomas, S. (2006). Professional learning communities: A review of the literature. Journal of Educational Change, 7(4), 221-258. https://doi.org/10.1007/s10833-006-0001-8.

Sutton, P. S., \& Shouse, A. W. (2016). Building a culture of collaboration in schools. Phi Delta Kappan, 97(7), 69-73. https://doi.org/10.1177/0031721716641653.

Tomacruz, S. (2018, September 25). Teachers complain of 'excessive' workload; DepEd says these are 'legal, necessary.' Rappler. https://www.rappler.com/nation/teachers-callout-excessive-workload-deped-says-legal-necessary.

Vescio, V., Ross, D., \& Adams, A. (2008). A review of research on the impact of professional learning communities on teaching practice and student learning. Teaching and Teacher Education, 24 (1), 80-91. https://doi.org/10.1016/j.tate.2007.01.004.

Watson, C. (2014). Effective professional learning communities?: The possibilities for teachers as agents of change in schools. British Educational Research Journal, 40(1), 18-29. https://doi.org/10.1002/berj.3025.

Williams, R., Brien, K., \& LeBlanc, J. (2012). Transforming schools into learning organizations: Supports and barriers to educational reforms. Canadian Journal of Educational Administration and Policy, 134, 1-32. http://136.159.200.199/index.php/cjeap /article/view/42834 